Westward Dharma 
This page intentionally left blank 


\section{Westward Dharma}

Buddhism beyond Asia

Edited by

CHARLES S. PREBISH

MARTIN BAUMANN

U NIVERSITY OF C A LIFORNIA PRESS

Berkeley Los Angeles London 
University of California Press

Berkeley and Los Angeles, California

University of California Press, Ltd.

London, England

(C) 2002 by the Regents of the University of California

Chapter $I$ is a revised version of "Night-Stand Buddhists and Other Creatures," chapter 5 of American Buddhism, edited by Duncan Ryūken Williams and Christopher S. Queen, published by Curzon Press in 1999.

Chapter 21 was adapted from portions of the introduction and chapter 3 of Christopher S. Queen's Engaged Buddhism in the West. () Christopher S. Queen 200o. Reprinted with permission of Wisdom Publications, 199 Elm Street, Somerville, MA 02144, U.S.A.

Library of Congress Cataloging-in-Publication Data

Westward Dharma : Buddhism beyond Asia / edited by Charles S. Prebish, Martin Baumann.

p. $\mathrm{cm}$.

Includes bibliographical references and index.

ISBN 0-520-22625-9 (Cloth : alk. paper) -

ISBN 0-520-23490-1 (Paper : alk. paper)

1. Buddhism-Missions-History. 2. Buddhism-2oth century-History. 3. Globalization-Religious aspects-

Buddhism. I. Prebish, Charles S. II. Baumann, Martin, 1960-

BQ5925.W47 2002

$294 \cdot 3^{\prime} 09-\mathrm{dc} 21$

2002000717

Manufactured in the United States of America

$\begin{array}{lllllllll}10 & 09 & 08 & 07 & 06 & 05 & 04 & 03 & 02\end{array}$

$\begin{array}{llllllllll}10 & 9 & 8 & 7 & 6 & 5 & 4 & 3 & 2 & 1\end{array}$

The paper used in this publication is both acid-free and totally chlorine-free (TCF). It meets the minimum requirements of ANSI/NISO Z39.48-1992 (R 1997) (Permanence of Paper). () 
In loving memory of Rick Fields, whose keen insight, incredible wit, trailblazing spirit, and delightful prose encouraged us in wonderful ways.

It is his work that nurtured all future studies of Western Buddhism. 
This page intentionally left blank 